\title{
TINJAUAN TERHADAP PLTS 24 KW ATAP GEDUNG PT INDONESIA POWER PESANGGARAN BALI
}

\author{
Ketut Vidhia Kumara ${ }^{1}$, I Nyoman Satya Kumara ${ }^{2}$, Wayan Gede Ariastina ${ }^{3}$ \\ Program Studi Teknik Elektro, Fakultas Teknik, Universitas Udayana Denpasar - Bali \\ Email: kvk1249@gmail.com ${ }^{1}$, satya.kumara@unud.ac.id ${ }^{2} \underline{\text { w.ariastina@unud.ac.id }}^{3}$
}

\begin{abstract}
ABSTRAK
PT. Indonesia Power unit Pesanggaran merupakan salah satu perusahaan pembangkit listrik yang ada di Bali, yang telah ikut dalam pengembangan energi terbarukan dengan memasang PLTS berkapasitas $24 \mathrm{KW}$. Penelitian ini dilakukan tinjauan teknis untuk mengetahui kondisi PLTS tersebut. Tinjauan dilakukan dengan mengobservasi keadaan dilapangan, data teknis komponen PLTS, dan juga wawancara dengan staf yang bertanggung jawab terhadap PLTS tersebut. Hasil tinjauan yang dilakukan didapat bahwa desain PLTS 24 KW tesebut sudah baik. Dikarenakan PTLS terletak pada lokasi geografi -8,72LS, 115,21 BT. Modul surya menghadap ke arah utara atau azimuth $0^{\circ}$. Modul ini diletakan di atap Gedung $A$, sehingga mengurangi biaya untuk penyangga dengan sudut kemiringan modul surya sebesar $22^{\circ}$ mendekati sudut kemiringan optimum. Komponen-komponen yang digunakan pada PLTS sudah baik. Baik itu modul surya tipe CHN240-60P polycrystalline silicon solar cells yang sudah memiliki sertifikat CE (Conformité Europeenne). Inverter yang digunakan adalah tipe gridconected ABB PVS300-TL-800W-2, dengan output AC $=8.000 \mathrm{~W}$ sebanyak 3 buah yang juga sudah memiliki sertifikat $C E$ dan yang lainnya. Kualitas spesifikasi teknis komponen teknis PLTS dan konfigurasi pemasangannya berpengaruh terhadap produksi energi PLTS dan hal ini sudah terimplementasi dengan baik pada PLTS 24 KW Indonesia Power.
\end{abstract}

Kata Kunci : Energi terbarukan, PLTS, sudut elevasi, orientasi modul

\begin{abstract}
PT. Indonesia Power unit Pesanggaran is one of the power generation companies in Bali, which has also participated in the development of renewable energy by installing solar PV with a capacity of $24 \mathrm{KW}$. In this research, reviews was conducted to know the condition of the solar PV plant. Review is carried out by conducting observation in the field, reviewing technical data of solar PV components, and also interviews with the staff who operate and maintain the solar PV. Through reviews it was found that the design and installation of solar PV plant is good and follows good practice of solar PV installation for optimum energy production. Due to plant location at GPS coordinate of -8,72, 115,21 therefore the solar module has been installed facing north or azimuth $0^{\circ}$. This module is placed on the roof of Building $A$, thereby reducing the cost to construct mechanical supports. The solar module was installed with a slope angle of $22^{\circ}$ approaching the optimum slope angle. The components of the PV plant are good as they bear international standards. The solar module is CHN240-60P polycrystalline silicon with 60 cells that caccries CE certificate (Conformité Europeenne). Also, the inverter is three units of $A B B$ PVS300-TL-800W-2 with AC output of 8,000 W which are also carries CE certificate and others. The quality of technical specifications of solar PV components and also installation of the plant has direct influence on the energy production of the plant and these have been properly implemented on the $24 \mathrm{KW}$ Indonesia Power solar PV plant.
\end{abstract}

Keywords: Renewable Energy, solar PV, inclination angle, orientation angle,

\section{PENDAHULUAN}


Kondisi kelistrikan nasional hingga akhir 2014 berdasarkan yang ada di Kementrian Energi dan Sumber Daya Mineral menunjukan total kapasitas terpasang pembangkit 53,585 MW. 70\% atau 37,280 MW disumbangkan oleh PLN, Independent Power Producer (IPP) sebesar 10.995 MW (20\%), Public Private Utility (PPU) sebesar 2.634 (5\%), dan Izin Operasi Non BBM (IO) sebesar 2.677 MW (5\%). Konsumsi energi rata-rata 199 TWh sedangkan produksi listriknya 228 TWh (hanya PLN dan IPP). Rasio elektrifikasi nasional tercatat sebesar 84,35\%. Pemakaian listrik pergolongan terbesar untuk golongan rumah tangga yaitu sebesar $43 \%$ disusul kemudian dengan industri sebesar 33\%, bisnis 18\%, dan terakhir 6\% publik [1]. Di Bali pada tahun 2016, diperkirakan beban puncak sistem kelistrikan Bali mencapai 822 megawatt [2]. Dengan kondisi sekarang Bali memang sudah aman dengan daya sisa kelistrikan lebih dari $30 \%$ daya yang ada. Akan tetapi semua pembangkit yang ada di Bali masih konvensional yang bahan bakunya bias habis beberapa tahun lagi. Salah satu solusi pemerintah menggulangi hal ini dengan membangun PLTS di berbagai daerah.

Kebijakan Energi Nasional Indonesia menyatakan bahwa pembangkit listrik terbarukan akan berkontribusi sekitar 10\% dari grid nasional pada tahun 2025. Saat ini, kapasitas listrik Indonesia hanya lebih dari $43 \mathrm{GW}$ dan diperkirakan mencapai lebih dari 65 GW pada tahun 2025, dengan sasaran energi terbarukan adalah sekitar 6,5 GW. Energi terbarukan harus dikembangkan lebih dari 34 daerah provinsi dengan memanfaatkan sumber daya lokal. Bali adalah pulau kecil dan salah satu provinsi yg ada di Indonesia dengan hampir empat juta penduduk dan luas tanah 5.600kilometer persegi. Bali tidak memiliki sumber daya konvensional maka semua bahan bakar berbasis fosil semua datang dari luar Bali. Untungnya, Bali memiliki berbagai sumber daya terbarukan yang dapat dimanfaatkan untuk pembangkit listrik. Sumber daya terbarukan yang tersedia di Bali yaitu mikro hidro, angin, fotovoltaik, biomassa, dan juga panas bumi. Pada 2014, jumlah pembangkit terbarukan telah mencapai $7 \mathrm{MW}$, yang terdiri dari 2,1 MW fotovoltaik, $736 \mathrm{~kW}$ tenaga angin, $45 \mathrm{~kW}$ mikro hidro, dan 4,174 MW biomassa. Energi terbarukan menyumbang sekitar 1\% dari total kapasitas listrik di Bali [3]. Pada bulan Februari 2013, dua PLTS skala besar masing-masing berkapasitas $1 \mathrm{MW}$ dipasang di desa Kubu Kabupaten Karangasem dan desa Kayubihi Kabupaten Bangli[4], [5]. Pada periode yang sama, enam PLTS stand alone yang masing-masing berkapasitas $15 \mathrm{~kW}$ juga di pasang[6].

Indonesia terletak di daerah katulistiwa sehingga memiliki intensitas penyinaran matahari yang baik sepanjang tahun. Kondisi penyinaran ini potensial untuk digunakan dalam pembangkitan listrik tenaga surya (PLTS). Pembangkit Listrik Tenaga Surya (PLTS) di Indonesia paling populer di-gunakan untuk listrik pedesaan, sistem seperti ini populer dengan sebutan SHS (Solar Home System). Karena skalanya yang kecil, sistem DC (direct current) lebih disukai, untuk menghindari losses dan self consumption akibat digunakannya inverter. SHS ini biasanya merupakan bantuan pemerintah yang diberikan secara subsidi dan masyarakat pedesaan menggunakan-nya sebagai sarana penerangan di malam hari untuk mengganti lampu minyak tanah. Dalam konteks ini terlihat bahwa pendekatan yang digunakan bersifat top-down sehingga selama ini perkembangan SHS sangat tergantung pada program pemerintah dan sejauh ini kontribusi energi listrik surya nasional masih sangat kecil[7]. Tetapi akhirakhir ini di Indonesia mulai menggunakan sistem grid interractive. Grid interractive pada dasarnya adalah mengg-abungkan PLTS dengan jaringan distribusi listrik (PLN). Sebagian orang menyebutnya dengan istilah Hybrid PLTS-PLN. Grid interractive umumnya digunakan pada jaringan interkoneksi. Kebanyakan penggunaan PLTS grid interractive dimotivasi oleh keinginan untuk menggunakan energi yang ramah lingkungan, dan untuk mengatasi ketidakstabilan pada tegangan (voltage sags, swells, spikes, dan noise), serta mengurangi penggunaan BBM pada sistem interkoneksi genset di wilayah pedesaan. 
Indonesia telah membangun PLTS kurang lebih 500 unit dari tahun 2011 dampai dengan 2016. Yang dilaporkan mengalami kerusakan ada sekitar 10\%, menurut Direktur Aneka Energi Baru dan Energi Terbarukan Kementrian ESDM, Maritje Hutapea. Umunya kerusakan ini terjadi pada komponen baterai dan inverter. Hal ini terjadi diakibatkan karena kurangnya perawatan dan biaya perbaikan yang cukup tinggi[8].

PT. Indonesia Power unit Pesanggaran merupakan salah satu perusahaan pembangkit listrik yang ada di Bali. PT. Indonesia Power unit Pesanggaran memiliki visi untuk menjadi perusahaan yang ramah lingkungan, maka perlu menerapkan penggunaan energi listrik yang ramah lingkungan. Salah satu yang kini banyak jadi pilihan adalah tenaga surya. Peran Indonesia Power Pesanggaran dalam pengembangan energi baru terbarukan adalah dengan membangun PLTS yang dibangun di atap gedung administrasi pembangkit PLTDG Pesanggaran dengan kapasitas 24 KW. PLTS yang berada di PT Indonesia Power Pesanggaran terdiri dari 96 buah modul surya, yang dibagi menjadi 4 array, yang masing-masing terangkai dari 24 buah modul. Tegangan listrik searah dirubah menjadi tegangan bolak balik menggunakan string inverter sistem 3 phase berkapasistas $8 \mathrm{KW}$ sebanyak 3 unit.

Berdasarkan latar belakang di atas dalam penelitian ini akan dilakukan tinjauan terhadap PLTS $24 \mathrm{KW}$ yang terletak di PT. Indonesia Power unit Pesanggaran untuk mengetahui kondisi komponen dan instalasi dari PLTS tersebut. Hal ini penting untuk diketahui karena kedua hal tersebut berpengaruh langsung terhadap unjuk kerja PLTS.

\section{KAJIAN PUSTAKA}

\subsection{SISTEM PEMBANGKIT LISTRIK TENAGA SURYA}

PLTS adalah suatu pembangkit listrik yang menggunakan sinar matahari melalui sel surya (photovoltaic) untuk mengubah radiasi sinar foton matahari menjadi energi listrik. Sel surya merupakan lapisan-lapisan tipis dari bahan semikonduktor silikon (Si) murni dan bahan semikonduktor lainnya. PLTS memanfaatkan cahaya matahari untuk menghasilkan listrik DC, yang dapat diubah menjadi listrik AC apabila diperlukan. PLTS tetap dapat menghasilkan listrik dalam cuaca mendung selama masih terdapat cahaya. Sistem PLTS dapat diklasifikan ke dalam beberapa jenis. Berdasarkan aplikasi dan konfigurasinya, secara umum PLTS dapat dibagi menjadi dua, yaitu sistem PLTS yang terhubung dengan jaringan (on-grid PV system) dan sistem PLTS yang tidak terhubung dengan jaringan (off-grid PV system) atau PLTS yang berdiri sendiri (stand-alone). PLTS stand-alone ini selain dapat beroperasi secara mandiri, juga dapat ditunjang oleh sumber daya lain seperti tenaga angin, generator set, maupun tenaga air serta tenaga mikro hidro yang disebut sebagai sistem PLTS hybrid. Berdasarkan lokasi pemasangannya, sistem PLTS dapat dibagi menjadi dua yaitu sistem PLTS pola tersebar (distributed PV system) dan sistem PLTS pola terpusat (centralized PV system)[9].

\subsection{KOMPONEN PLTS}

\subsubsection{MODUL}

Komponen dasar dari PLTS adalah sel surya sebagai tempat konversi radiasi matahari menjadi arus listrik. Sel ini terdiri dari lapisan tipis bahan semikonduktor, yang umumnya terbuat dari pengolahan silikon dengan ketebalan sekitar 0,3 $\mathrm{mm}$ dan dengan permukaan dari 100 hingga 225 $\mathrm{cm}^{2}$. Silikon memiliki 4 elektron valensi (tetravalensi), didoping dengan atom trivalensi (misalnya boron untuk doping $P$ ) pada satu lapisan dan sejumlah atom pentavalensi (misalnya fosfor untuk doping N) pada lapisan lainnya. Dengan demikian, maka daerah tipe-P kelebihan lubang (holes), sedangkan daerah tipe- $\mathrm{N}$ kelebihan elektron[10]. Adanya lubang dan elektron inilah yang menyebabkan terjadinya perpindahan elektron, ketika terkena sinar matahari. 


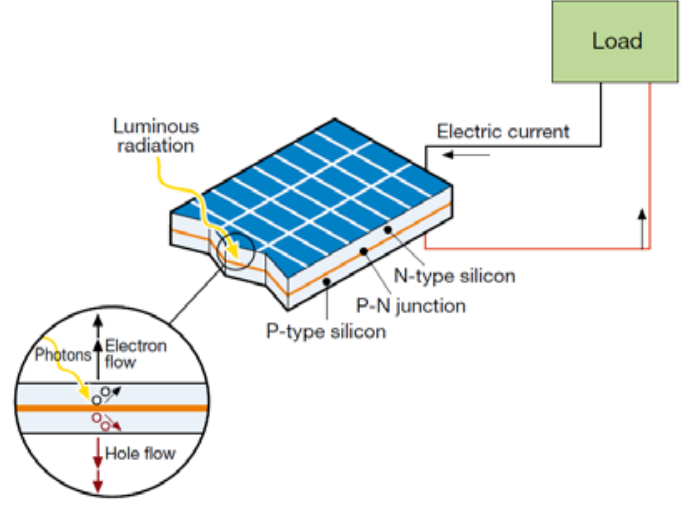

Gambar 1. Prinsip Kerja Sel Surya [10]

\subsubsection{INVERTER}

Inverter merupakan peralatan elektronika yang berfungsi untuk mengubah arus listrik searah (DC) dari panel surya atau baterai menjadi arus listrik bolak-balik (AC) dengan frekuensi 50/60 Hz. Pada PLTS, inverter satu phase biasanya digunakan untuk sistem dengan beban yang kecil sedangkan untuk inverter tiga phase digunakan untuk sistem dengan beban yang besar maupun sistem yang terhubung dengan jaringan PLN (gridconnected)[10].

Kondisi tenaga listrik (power condition) dan sistem kontrol pada system PLTS diperankan oleh inverter, yang memiliki fungsi merubah arus bilak balik (direct current) yang dihasilkan oleh modul surya menjadi listrik bolak balik (alternating current), dan dikontrol kualitas dari daya listrik yang dikeluarkan untuk dikirim ke beban atau ke jaringan listrik. Pada PLTS penggunaan inverter satu fasa biasanya untuk sistem yang bebannya kecil, sedangkan untuk sistem yang besar dan terhubung dengan jaringan utilitas (PLN) biasanya digunakan inverter 3 fasa [4].

\subsection{INKLINASI DAN ORIENTASI PANEL SURYA}

Efisiensi terbesar panel surya tercapai jika sudut datang sinar matahari selalu $90^{\circ}$. Sesungguhnya datangnya sinar matahari bervariasi menurut garis lintang serta deklinasi matahari sepanjang tahun. Karena kemiringan sumbu rotasi bumi sekitar $23,45^{\circ}$ terhadap bidang orbit bumi terhadap matahari, tempat terbit dan terbenamnya mathari selalu bervariasi setiap harinya. Matahari berada di posisi sudut $90^{\circ}$ terhadap permukan bumi yaitu pada garis khatulistiwa. Untuk mengetahui ketinggian maksimum (dalam derajat) ketika matahari mencapai langit $(\alpha)$, secara mudah menggunakan persamaan berikut[10]:

$$
\alpha=90^{\circ}-\text { lat }+\delta \text { ( } N \text { hemisphere); }
$$$$
90^{\circ}+\text { lat }-\delta \text { (Shemisphere) }
$$

Dimana:

Lat adalah garis lintang (latitude) lokasi instalasi panel surya terpasang (dalam satuan derajat). $\delta$ adalah sudut dari deklinasi matahari $\left(23,45^{\circ}\right)[10]$.

Orientasi panel surya bisa ditunjukkan dengan sudut azimuth $(\gamma)$ penyimpangan terhadap arah selatan (untuk lokasi di belahan bumi utara) atau arah utara (untuk lokasi di belahan bumi selatan). Azimuth adalah besar sudut antara utara magnetis (nol derajat) dengan titik atau sasaran dituju. Nilai sudut azimuth positif menunjukkan orentasi ke barat, sedangkan nilai azimuth negatif menunjukkan orientasi ke timur. Berkenaan dengan pemasangan panel secara ground-mounted, kombinasi inklinasi dan orientasi menentukan arah panel terebut, seperti terlihat pada Gambar 2. Hal ini berkebalikan, ketika panel dipasang pada atap bangunan, arah panel ditentukan oleh inklinasi dan orientasi atap bangunan[10].

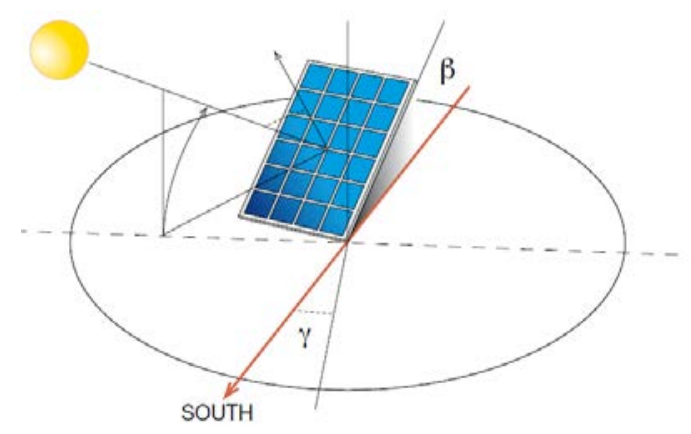

Gambar 2. Inklinasi dan Orientasi Menentukan Arah Panel [10]

Iklinasi dan orientasi sebuah modul surya juga berpengaruh terhadap hasil produksi energinya. Seperti yang diketahui jika sudut kemiringan tepat atau optimum maka daya output dari modul juga akan 
optimum sehingga sudut kemiringan modul juga memperngaruhi produksi dari sebuah PLTS [10].

\section{METODE PENELITIAN}

Penelitian ini dilakukan di PT. Indonesia Power unit Pesanggaran Jl. By Pass Ngurah Rai, Denpasar, Bali dengan data penelitian yang bersumber dari data sheet komponen, data dari observasi di PT. Indonesia Power Pesanggaran maupun data dari hasil wawancara dari Staf PT. Indonesia Power unit Pesanggaran.

Langkah pertama yang dilakukan untuk penelitian ini adalah dengan mengobservasi di lapangan tentang PLTS tersebut. Observasi difokuskan kepada desain system dan juga komponen komponen yang ada pada PLTS yang berdapa pada atap Gedung A PT. Indonesia Power Pesanggaran. Langkah selanjutnya dengan mengumpulkan data data sekunder yang dapat mendukung penelitian ini, baik itu berupa data sheet maupun data yang didapat dari staf pegawai PT. Indonesia Power Pesanggaran. Setelah semua data terkumpul maka kita akan melakukan audit teknis terhadap PLTS tersebut. Selain dari tahapan-tahapan yang dijelaskan sebelumnya kita juga akan melakukan beberapa wawancara kepada staf pegawai yang bertanggung jawab terhadap PLTS, guna untuk mengetahui bagaimana maintenece yang dilakukan untuk merawat dan menjaga performa dari PLTS tersebut.

\section{HASIL DAN PEMBAHASAN}

\subsection{DESAIN SISTEM PLTS $24 \mathrm{KW}$ INDONESIA POWER PESANG- GARAN}

Berdasarkan hasil observasi pada PLTS yang ada di Indonesia Power (IP) Pesanggaran dapat di tunjukan bahwa, PLTS memiliki kapasitas daya total $24 \mathrm{kWp}$. PLTS yang berada di Indonesia Power Pesanggaran memiliki 96 buah modul, yang terdiri dari daya setiap modulnya $240 \mathrm{Wp}$ tipe poly crytaline. Total keseluruh modul tersebut dapat memiliki kapasitas daya pembangkit sebesar $23 \mathrm{kWp}$. Keseluruhan modul surya dibagi menjadi 12 array yang masing-masing array terdiri dari 8 modul yang terhubung seri. Mengubah output daya listrik searah menjadi daya listrik bolak balik, dipergunakan string inverter sistem 3 phase dengan kapasitas $8 \mathrm{~kW}$ sebanyak 3 unit. PLTS ini digunakan untuk mensuplai beban gedung administrasi di Indonesia Power Pesanggaran. Dari sisi modul PLTS ini memiliki kapasitas $23 \mathrm{~kW}$, namun dari sisi inverter menggunakan $24 \mathrm{~kW}$, untuk selanjutnya PLTS ini disebut PLTS $24 \mathrm{~kW}$ IP. PLTS ini dimiliki oleh Indonesia Power Pesanggaran. Pemasangan sistemnya dipasang oleh pihak luar yaitu Contained Energy.

PLTS $24 \mathrm{~kW}$ IP terletak pada lokasi geografi -8,72 lintang selatan (latitude), dan 115,21 bujur timur (longitude). PLTS ini terpasang di atas atap gedung administrasi PT. Indonesia Power Pesanggaran dengan luas atap $826.59 \mathrm{~m}^{2}$. PT. Indonesia Power Pesanggaran beralamat di Jalan By Pass Ngurah Rai No.535, Pedungan. PLTS dibangun dibagian utara dari atap gedung administrasi yang menghadap langsung ke jalan raya atau ke arah utara. Sehingga orientasi modul surya menghadap ke utara mengikuti atap gedung. Sudut kemiringan modul mengikuti atap gedung tersebut. Sudut ke-miringan atap gedung adalah $22^{\circ}$. Gambar 3. menunjukan lokasi gedung administrasi PT. Indonesia Power pesanggaran yang dilihat melalui google maps. Modul surya yang berada di atap gedung administrasi Indonesia Power Pesanggaran dapat di lihat pada Gambar 4. Gambar tersebut diambil dari bagian depan dari PT Indonesia Power Pesanggaran, yang menunjukan Modul di pasang di atas atap. 


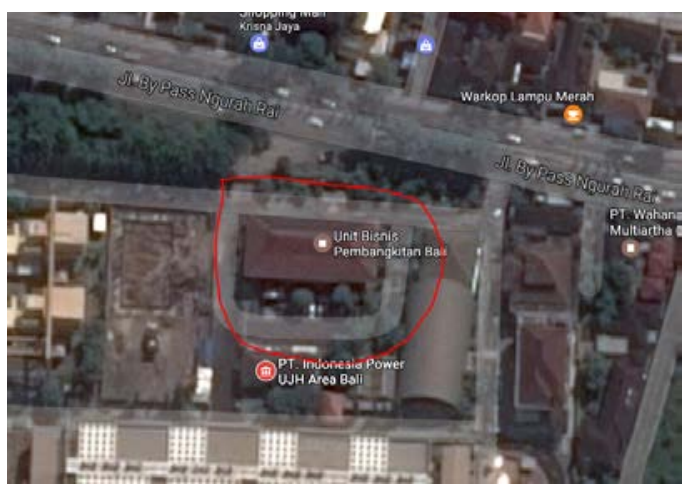

Gambar 3. Lokasi PLTS 24 kW IP

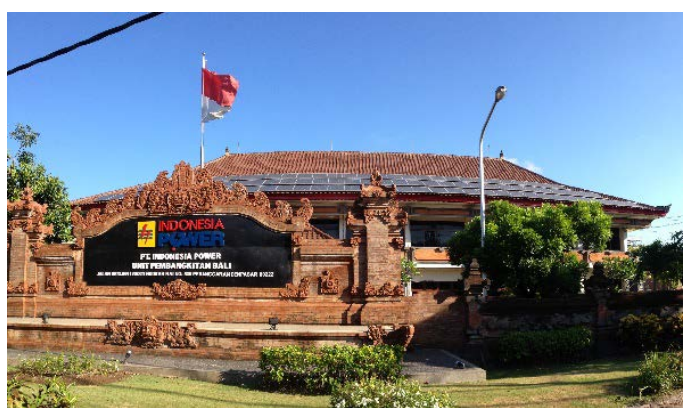

Gambar 4. PLTS 24 kW IP

\subsection{ANALISA KONFIGURASI SIS- TEM PLTS $24 \mathrm{KW}$ INDONESIA POWER}

Secara umum penentuan konfigurasi sistem PLTS 24 kW IP dapat dipaparkan kedalam perhitungan sistem (system sizing) sebagai berikut:

\subsubsection{MODUL SURYA}

Modul surya yang digunakan oleh PLTS 24 kW IP adalah Modul Surya tipe CHN240-60P polycrystalline silicon solar cells with 60 cells. Modul surya memiliki kapasitas $240 \mathrm{Wp}$. Spesifikasi modul surya sebagai berikut:

$$
\begin{aligned}
& \text { Imp }=6,99 \mathrm{~A} ; \mathrm{Vmp}=34,5 \mathrm{~V} ; \\
& \mathrm{Voc}=43,2 \mathrm{~V} ; \mathrm{ISC}=7,73 \mathrm{~A} \\
& \text { NOCT }=48^{\circ} \mathrm{C} ; \\
& \text { Temp. Coefficient of } \mathrm{P}=0.5 \% / \mathrm{K} ; \\
& \text { Temp. Coefficient of } \mathrm{Voc}=-0,125 \mathrm{~V} / \mathrm{K} ; \\
& \text { Temp. Coefficient of } \mathrm{Isc}=0,06 \% / \mathrm{K}
\end{aligned}
$$

Gambar 5. menujukan modul yang terpasang di atap gedung administrasi PT.
Indonesia Pesanggaran. Menyebabkan

\begin{tabular}{|c|c|c|}
\hline \multicolumn{3}{|c|}{ Mechanical\&Packaging Characterisics } \\
\hline $\begin{array}{l}\text { Dimensions } \\
\text { (length/width/thic } \\
\text { kness) }\end{array}$ & $m m$ & $1640 \times 990 \times 40$ \\
\hline Cable Length & $\mathrm{mm}$ & 900 \\
\hline Weight & $\mathrm{kg}$ & 21 \\
\hline $\begin{array}{l}\text { Number of instal- } \\
\text { lation Holes in } \\
\text { Frame }\end{array}$ & & 8 \\
\hline Construction & & $\begin{array}{l}\text { Superstrate: High } \\
\text { transmission } \\
3.2 \mathrm{~mm} \text { tempered } \\
\text { low iron glass; } \\
\text { Substrate: White } \\
\text { BackSheet; } \\
\text { Encapsulant: Fast } \\
\text { Cure EVA }\end{array}$ \\
\hline Frame & & $\begin{array}{l}\text { Clear anodized } \\
\text { aluminium alloy } \\
\text { type 6063T5; } \\
\text { Color: silver }\end{array}$ \\
\hline $\begin{array}{l}\text { Packing Configura- } \\
\text { tion and Quantity } \\
\text { per Pallet }\end{array}$ & & $\begin{array}{l}26 \text { pcs per carton } \\
\text { and one carton per } \\
\text { pallet }\end{array}$ \\
\hline $\begin{array}{l}\text { Container Loading } \\
\text { Capacity }\end{array}$ & & $\begin{array}{l}344 \text { pcs per } 20 \mathrm{ft} \\
\text { cubic } \\
\text { tainer; } 728 \text { pcs per } \\
40 \mathrm{ft} \text { cubic con- } \\
\text { tainer }\end{array}$ \\
\hline
\end{tabular}
arah dan sudut kemiringan modul mengikuti atap

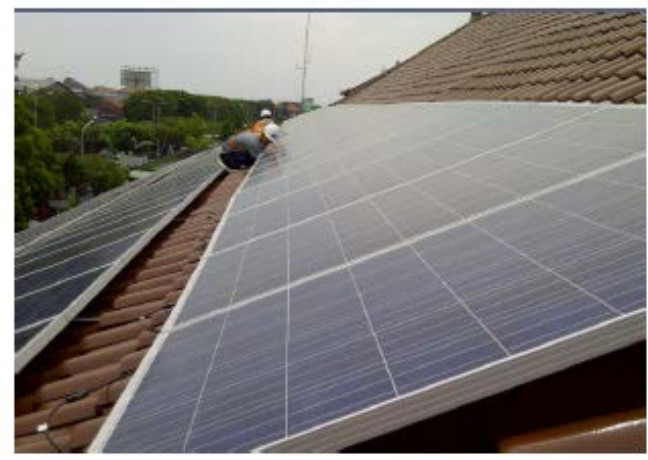

Gambar 5. Modul surya CHN240-60

Tabel 1. Karakteristik Mekanik Dan kemasan 
Spesifikasi dan karakteristik yang ada diatas adalah modul yang digunakan oleh PLTS ini sudah sangat baik, karna menggunakan modul 60P polycrystalline silicon solar dengan 60 cell dengan kapasitas $240 \mathrm{Wp}$ dengan dimensi tinggi 1640 $\mathrm{mm}$, lebar $990 \mathrm{~mm}$, dan ketebalan $40 \mathrm{~mm}$ yang sangat cocok untuk dipasang di atas sebuah gedung. Selain dari spesifikasi dan karakteristik yang baik modul ini juga memiliki beberapa fitur dan juga sudah di sertifikat CE (Conformité Europeenne). Selain itu juga modul ini mendapat jaminan dari produsen selama 25 tahun.

\subsubsection{INVERTER}

Inverter yang digunakan oleh PLTS 24 kW IP adalah Inverter tipe grid-conected ABB PVS300-TL-800W-2, dengan output $A C=8000 \mathrm{~W}$. Spesifikasi inverter sebagai berikut:
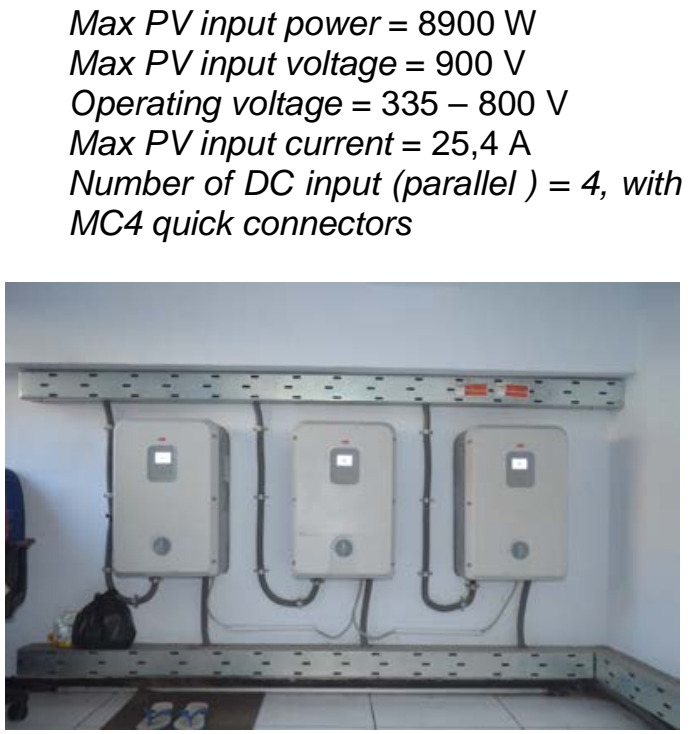

Gambar 6. Inverter ABB PVS300-TL-800W-2

Jumlah inverter yang di gunakan PLTS ditentukan oleh kapasitas daya PLTS dan kapasitas daya inverter yang digunakan, yaitu: $24 \mathrm{kWp} / 8 \mathrm{~kW}=3$ unit. Kemudian berdasakan karakteristik dari modul surya dan inverter yang digunakan, konfigurasi dari jumlah modul surya perarray untuk PLTS 24 kW IP adalah 8 buah. Berdasarkan kapasi-tas daya modul surya perarray, untuk mem-bangkitkan PLTS dengan kapasitas $23 \mathrm{kWp}$ diperlukan array sejumlah $23.000 \mathrm{Wp} /(240 \mathrm{Wp} \times 8$ buah $)=$ 12 array.

Jadi total keseluruhan modul surya yang digunakan adalah $12 \times 8=96$ unit, dengan total kapasistas $23.040 \mathrm{Wp}$. Untuk setiap unit inverter akan memiliki input array sejumlah, setiap inverter 12/3 $=4$ inputan.

Dari data sheet inverter dan juga konfigurasi yang digunakan pada PLTS di PT. Indonesia Power Pesanggaran bisa dikatakan baik, ini disebabkan PLTS ini menggunakan 3 inverter yang berkapasitas $8 \mathrm{~kW}$. Peng-gunaan 3 inverter ini lebih efektif ketimbang menggukan hanya satu inverter deng-an kapasitas yang sama sebesar $24 \mathrm{~kW}$. Bisa dikatakan lebih baik karena menurut hasil wawancara dengan staf yang bertang-gung jawab atas PLTS ini pernah terjadi kerusakan pada salah satu inverter, namun tidak mempengaruhi dua inverter lainnya untuk memproduksi energi. Jadi pemilihan 3 inverter sangat tepat dibandingkan meng-gunakan hanya satu inverter saja. Namun dari hasil observasi yang dilakukan, inverter ini hanya merekam produksi energi selama satu tahun. Setelah melewati bulan 12 maka data produksi energi tersebut tidak terekam lagi atau mulai dari bulan Januari kembali.

Inverter ini juga sudah di sertifikasi oleh CE (Conformité Europeenne), yang berarti sudah memenuhi kualifikasi keamanan di Eropa. Selain sertifikasi CE, juga sertiifikat dari RoHS merupakan singkatan dari Restriction of Hazardous Substances. Dan secara sederhana dapat dijelaskan bahwa RoHS merupakan suatu kebijakan yang mengatur tentang pengurangan kandungan zat-zat berbahaya yang masuk dalam produk elektronik dan listrik yang dilakukan diawal siklus produk. Maksud dari diawal siklus produk adalah bahwa penerapan kebijakan RoHS Compliance itu dilakukan mulai dari tahapan perencanaan design produk.

\subsection{ORIENTASI DAN INKLINASI PLTS INDONESIA POWER}

Orientasi dan inklinasi/kemiringan panel surya pada lokasi PLTS 24 kW IP (- 
8,72 LS, 115,21 BT,) dapat ditentukan dengan cara sebagai berikut:

a. Orientasi panel surya, dilihat dari lokasi PLTS $24 \mathrm{~kW}$ Indonesia Pesangaran yang terletak pada belahan bumi selatan (-8,72 LS) dan menggunakan kontruksi peyangga tipe tetap (mengikuti atap gedung). Maka agar mendapatkan iradiasi optimum, maka panel surya diarahkan menghadap utara. Memperjelas kita sudah uji dengan kompas seperti pada Gambar 7. Yang memperlihatkan bahwa PLTS tersebut menghadap ke utara yang berarti azimuth $0^{\circ}$. Kompas yang digunakan adalah aplikasi yang ada di handphone yang sudah dilengkapi dengan GPS (Global Positioning System).

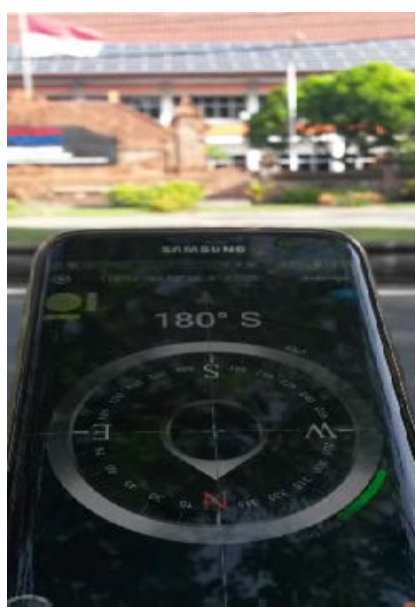

Gambar 7. Kompas untuk menunjukan arah modul surya

b. Inklinasi/kemiringan panel $(\beta)$ ditentukan dengan mencari terlebih dahulu nilai ketinggian optimum matahari dalam derajat $(\alpha)$ dengan menggunakan persamaan 2.4 yaitu:

$\alpha=90^{\circ}+$ lat $-\delta$

$=90^{\circ}+8,72^{\circ}-23,45^{\circ}=75,32^{\circ}$,

maka $\beta=180^{\circ}-\left(90^{\circ}+75,32^{\circ}\right)=$ $14,89^{\circ}$

Jadi kemiringan modul surya optimum $(\beta)$ adalah sebesar $14,89^{\circ}$.
Hasil observasi di lapangan dan berdasarkan informasi dari Indonesia Power bahwa sudut kemiringan modul surya pada loka-si PLTS 24 kW IP mengikuti sudut kemiri-ngan atap yaitu $22^{\circ}$. Kemiringan modul surya ini melebihi dari sudut optimum. Modul surya ini di letakan diatas atap Gedung $A$, sehingga hal ini dapat mengurangi biaya dari pembuatan penyangga.

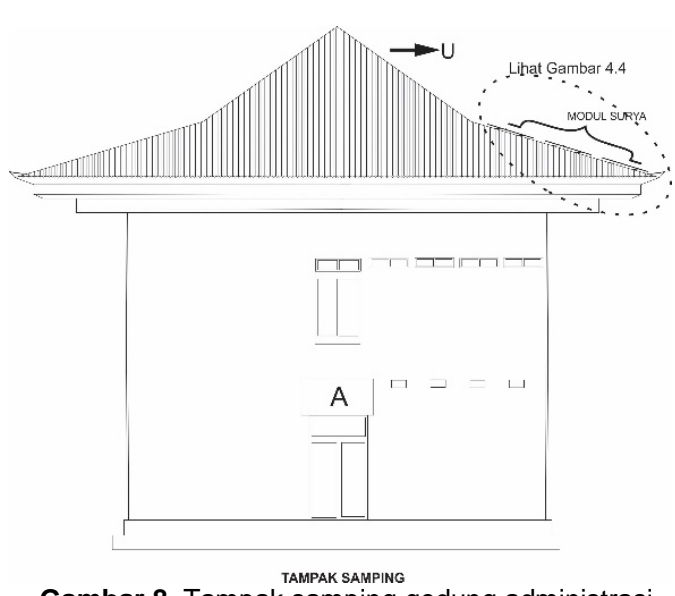

Gambar 8. Tampak Samping gedung administrasi Indonesia Power Pesanggaran.

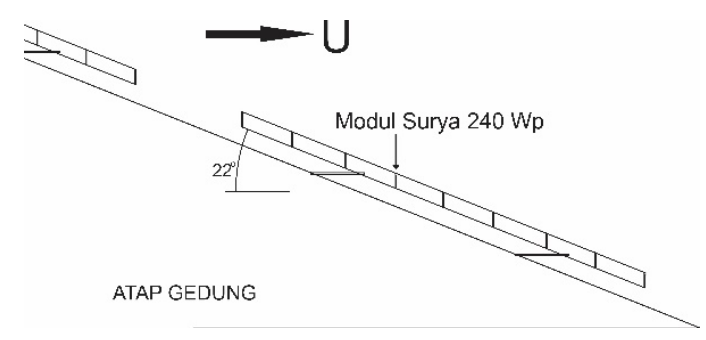

Gambar 9. Sudut kemiringan modul surya PLTS

Gambar 9. merupakan gambar yang menunjukan sudut kemiringan atap dari gedung A PT. Indonesia Power Pesanggaran yang memiliki sudut kemiringan sebesar $22^{\circ}$.

Hasil observasi di lapangan dan berdasarkan informasi dari Indonesia Power bahwa sudut kemiringan modul surya pada lokasi PLTS $24 \mathrm{~kW}$ IP mengikuti sudut kemiringan atap yaitu $22^{\circ}$. Kemiringan modul surya ini melebihi dari sudut optimum. Modul surya ini di letakan di atas atap Gedung $A$, sehingga hal ini dapat 
mengurangi biaya dari pembuatan penyangga.

\subsection{PERAWATAN TERHADAP PLTS}

Hasil observasi dan wawancara yang dilakukan kepada staf bahwa PLTS ini dari awal dibangun tahun 2012 sampai sekarang sama sekali tidak pernah dibersihkan. Hal ini disebabkan karena letak dari modul yang berada pada atap gedung dan akses menuju ke atap gedung tidak ada. Hal ini dapat menyebabkan penurunan produksi energi pada modul dikarenakan jika modul yang di-gunakan kotor maka intensitas menangkap sinar matahari juga akan berkurang.

\section{KESIMPULAN}

Penelitian yang sudah dilakukan dapat ditarik kesimpulan sebagai berikut:

a. Desain dari sistem PLTS $24 \mathrm{~kW}$ IP sudah baik. PLTS terletak pada lokasi geografi -8,72LS, 115,21 BT. Modul surya menghadap ke arah utara atau azimuth $0^{\circ}$. Modul ini diletakan di atap Gedung $A$, sehingga mengurangi biaya untuk penyangga dengan sudut kemiringan modul surya sebesar $22^{\circ}$ mendekati sudut kemiringan optimum yaitu $15^{\circ}$

b. Komponen-komponen yang diguna-kan pada PLTS sudah berkualitas baik. Baik itu Modul 24 kW IP adalah Modul Surya tipe CHN240-60P polycrystalline silicon solar cells with 60 cells. Maupun dari sisi inverter tipe grid-conected ABB PVS300-TL-800W-2, dengan output $A C=8000 \mathrm{~W}$ sebanyak 3 buah, yang lebih optimal dibandingan hanya dengan menggunakan hanya satu invereter saja. Kualitas komponen ini juga sudah berstandar internasional dengan sertifikat (Conformité Europeenne) dan RoHS (Restriction of Hazardous Substances). c. Perawatan dan pemeliharaan pada PLTS ini yang sangat kurang karena sejak dibangun 2012 sampai seka-rang modul dari PLTS ini tidak per-nah sama sekali di bersihkan, di-sebabkan akses untuk naik ke atap gedung tidak ada.

\section{DAFTAR PUSTAKA}

[1] "Kondisi Kelistrikan Nasional Saat Ini." [Online].Available: http://www2.esdm.go.id/berita/39listrik/7169-kondisi-kelistrikan-nasional-saat-ini.html. [Accessed: 25Nov-2016].

[2] "Grafik Beban Puncak." [Online]. Avail-

able:http://www.plnbali.co.id/apd/. [Accessed: 25-Nov-2016].

[3] I. Kumara, W. Ariastina, I. Sukerayasa, and I. Giriantari, "On the potential and progress of renewable electricity generation in Bali," in Information Technology and Electrical Engineering (ICITEE), 2014 6th International Conference on, 2014, pp. 1-6.

[4] I. A. Setiawan, I. S. Kumara, and I. W. Sukerayasa, "Analisis Unjuk Kerja Pembangkit Listrik Tenaga Surya (PIts) Satu MWP Terinterkoneksi Jaringan di Kayubihi, Bangli," Maj. IIm. Teknol. Elektro, vol. 13, no. 1.2014, 2014.

[5] I. S. Kumara, W. Ariastina, I. Sukerayasa, and I. Giriantari, "1 MWp grid connected PV systems in the village of Kayubihi Bali; Review on location's characteristics and its technical specifications," in Information Technology and Electrical Engineering (ICITEE), 2013 International Conference on, 2013, pp. 306-311.

[6] I. G. A. Putra, I. Giriantari, and I. Kumara, "Studi Sistem Pengelolaan PLTS $15 \mathrm{~kW}$ Stand Alone Dengan Metode Kano Di Dusun Yeh Mampeh Kabupaten Bangli," Teknol. Elektro, vol. 14, no. 1, 2015.

[7] N. S. Kumara, "Pembangkit listrik tenaga surya skala rumah tangga urban dan ketersediaannya di Indone- 
sia," Teknol. Elektro, vol. 9, no. 1, pp. 68-75, 2010.

[8] "Pemerintah Telah Bangun 500 PLTS, 50 dalam Kondisi Rusak." [Online]. Available: https://finance.detik.com/energi/d-

3189110/pemerintah-telah-bangun500-plts-50-dalam-kondisi-rusak. [Accessed: 02-Jul-2018].

[9] "Types of PV Systems." [Online]. Available:

http://www.fsec.ucf.edu/en/consumer/so-

lar_electricity/basics/types_of_pv.htm. [Accessed: 02-Jul-2018].

[10] A. Sace, "Technical Application Papers No. 10-Photovoltaic plants," Div. ABB SpALV Break., 2010. 